\title{
Ecosystem Services and Urban Planning: A Review of the Contribution of the Concept to Adaptation in Urban Areas
}

\author{
Andresa Ledo Marques ${ }^{1,2, *(\mathbb{D})}$, Angélica Tanus Benatti Alvim ${ }^{1}\left(\mathbb{D}\right.$ and Jörg Schröder ${ }^{2}(\mathbb{C})$ \\ 1 Graduate Program in Architecture and Urbanism, School of Architecture and Urbanism, Mackenzie \\ Presbyterian University, Sao Paulo 01302-907, Brazil; angelica.alvim@mackenzie.br \\ 2 Institute of Urban Design and Planning, Leibniz Universität Hannover, 30419 Hannover, Germany; \\ schroeder@staedtebau.uni-hannover.de \\ * Correspondence: andresa.ledo@staedtebau.uni-hannover.de or andresaledo.marques@mackenzista.com.br; \\ Tel.: +55-11-2114-8792
}

\begin{abstract}
The effects of climate change have a negative impact on urban areas and projections indicate these impacts will worsen in the coming years. In this context, cities need to adapt to the adverse effects of climate change. Potential solutions proposed in the literature for this adaptation include the use of Ecosystem Services. However, of the large volume of publications, few articles provide a structured analysis of the contribution and use of the concept in urban planning and adaptation to climate change. The objective of the present study was to review the literature on the subject and provide a structured analysis of the state of the art, main authors, countries, and references addressing the topic, together with key concepts emerging from this research, and challenges for future studies. Thus, a hybrid method of bibliometric analysis and in-depth reading of key articles held on the Web of Science electronic database was applied. The results revealed a growing scientific interest in the subject, a trend of greater interdisciplinarity in research, use of different evaluation methods, both economic and non-economic, and a systemic perspective that approaches sustainability not only as an environmental problem, but as a complex phenomenon.
\end{abstract}

Citation: Marques, A.L.; Alvim, A.T.B.; Schröder, J. Ecosystem Services and Urban Planning: A Review of the Contribution of the Concept to Adaptation in Urban Areas. Sustainability 2022, 14, 2391. https://doi.org/10.3390/su14042391

Academic Editor: Brian Deal

Received: 23 December 2021

Accepted: 15 February 2022

Published: 19 February 2022

Publisher's Note: MDPI stays neutral with regard to jurisdictional claims in published maps and institutional affiliations.

Copyright: () 2022 by the authors. Licensee MDPI, Basel, Switzerland. This article is an open access article distributed under the terms and conditions of the Creative Commons Attribution (CC BY) license (https:// creativecommons.org/licenses/by/ $4.0 /)$.

\section{Introduction}

\subsection{Research Problem and Objective}

Climate change, a global phenomenon strongly influenced by human activity, negatively impacts urban environments, placing cities front and center of discussions on adaptation to climate change. The relevance of this topic lies in the alarming projections of the adverse effects of climate change, with urban environments at particularly high risk and vulnerability given the large contingent of the population that resides in urban areas. In $2018,55 \%$ of the world's population lived in cities and, according to projections, two-thirds of the world's population will be urban by 2050 [1]. Although accurately determining the adverse effects of climate change on the urban environment is fraught with uncertainty, some of the main expected effects include: a general increase in sea level, frequency of storms and extreme precipitation events, heat stress and heat islands, floods, landslides, droughts, pollution, water shortages, wildfires, infections, and parasitic diseases [2,3].

This scenario calls for adaptation measures in urban environments, prompting numerous research approaches examining the issue. As part of the quest for solutions promoting adaptation of cities to climate change, there is growing interest from professionals and researchers in exploiting the benefits of nature as a valid approach for urban planning and, in this context, many authors cite the concept of Ecosystem Services (ESs) [4-8].

Seminal literature reviews, such as those by Demuzere et al. [9] and Salmond et al. [10], systematized ES benefits for climate change adaptation in urban areas. Other authors 
have focused on case studies and/or analysis in Geographic Information System software. Norton et al. [11] explored the potential of green infrastructure for mitigating high urban temperatures. Gill et al. [12] discussed the role of green infrastructure in climate change adaptation based on the case of Greater Manchester, while Geneletti et al. [13] reported an analysis of the use of Ecosystem-based adaptation in European urban climate adaptation plans.

However, of the large volume of publications, few papers provide a structured analysis of the contribution and use of the ESs concept in urban planning. Some reviews contribute to the discussion by focusing mainly on conceptual definitions. The study of Pauleit et al. [14] characterized the concepts of Green Infrastructure (GI), Ecosystem-based Adaptation (EbA), Nature-based Solutions (NbS), and ESs, and examined their interrelationships and overlaps. Other investigations provide a structured analysis of specific concepts (e.g., NbS, EbA, or GI), such as the studies by Nesshöver et al. [15], O'Sullivan et al. [16], Chatzimentor et al. [17], Brink et al. [18], and Matsler et al. [19].

Guerry et al. [20] argued that the pace of research on ESs has increased greatly in the last decade, but this increase has been accompanied by inconsistent and confusing use of terms. Tan et al. [21], in an article describing a conceptual framework to untangle the concept of Urban Ecosystem Services, showed that about half of the 319 papers reviewed by the authors on Urban Ecosystem Services provided no definition of ESs, demonstrating that many studies cite the concept imprecisely, failing to address its systemic nature. In addition, the data set of the quantitative stage of the present study shows that of the 316 articles collected, only 21\% cite the Millennium Ecosystem Assessment report [22], 15\% the article by Bolund and Hunhammar [23], and 18\% the article by Gómez-Baggethun et al. [24], which are central references for this debate (Supplementary Data).

Considering this background, the objective of the present study was to review the literature addressing the use of ESs for climate change adaptation in urban areas, and to provide a structured analysis of the state of the art, trends, main authors, countries, and references addressing the topic, key concepts emerging from this research, and challenges for future studies. To this end, a hybrid method of bibliometric analysis was employed entailing in-depth reading of key articles retrieved from the Web of Science (WoS) electronic database published between 2000 and 2020.

The present study was divided into four sections: the first part, comprising this introduction, states the research problem and objective, and provides a brief introduction on the concept of ESs, while the second part outlines the method employed for the present review of the literature. In the third part, the results of applying the method are presented, including the main articles retrieved, along with the prominent authors of seminal studies in the main journals worldwide, providing a picture of the current state of the art and evolution of the concept. Subsequently, the articles with greatest impact identified by the bibliographic analysis were examined in more detail to reveal the methods used by authors and to determine whether they associated ESs with adaptation to climate change in urban areas. Lastly, the results found formed the basis for a critical discussion centring on the following three points: (1) scientific interest and interdisciplinarity; (2) research approaches; and (3) challenges for future studies in urban areas.

\subsection{Brief Introduction to the Concept}

Human beings are inherently dependent on ESs, defined as the direct and indirect benefits that humans obtain from nature $[22,25]$. We depend on nature for producing food, for products, water, and also for ensuring favorable climatic conditions for our survival. However, natural resources have been exploited in an extractivist and predatory manner, leading to degradation of ecosystems, i.e., a continual reduction in the ability of ecosystems to provide these services.

Degradation of ecosystems and global climate change are causing an increase in adverse weather events, such as extreme heat waves, droughts, cyclones, and natural forest fires. These events have grim implications and pose new risks on a local, regional, and 
global scale. With regard to cities, the Intergovernmental Panel on Climate Change (IPCC) projections for increased vulnerability of urban communities are alarming and cite risks to health and human life, besides material and economic losses, landslides, air pollution, floods, thermal stress, and water shortages, among others [26].

The views which pervaded environmental narratives of the 1960s and 70s involved sustainable development approaches supported chiefly by governments. In the 1990s, particularly after the Brundtland report, the notion of incorporating multiple actors in the devising of public policies and agendas promoting sustainability prevailed [27].

Amid discussions concerning environmental degradation and the need to review the development model, several pivotal events took place in which the United Nations (UN) played a key institutional-political role. Rio92 (United Nations Conference on Environment and Development) had a central role in formulating the global guidelines and agenda for tackling climate change and global warming (United Nations Framework Convention on Climate Change-UNFCCC), which involved a commitment by most industrialized nations to implement the framework guidelines and control their country's emissions of greenhouse gases [28].

After Rio92, other important milestones were reached, with more ambitious targets, such as the Kyoto Protocol agreed at the 3rd Conference of the Parties (COP3) in 1997. Subsequently, other COPs and accords involving signatory member-countries of the UN emerged, with the goal of discussing sustainable development models and tackling climate change. Although there has been heavy criticism for breaching of these agreements, and concerns over the need to establish more effective models of governance for meeting targets [29], these agreements still play an important role on an international level.

In the context of this work, notable among the initiatives fostered by the UN is the Millennium Ecosystem Assessment (MEA). Called for by the then-Secretary-General of the UN, Kofi Annan in the 2000s, the MEA addressed sustainable development from a systemic perspective, considering human well-being and the guarantee of ESs as pivotal elements for new development perspectives.

The aim of the assessment was to gain an understanding of the consequences of ecosystem change for human well-being and of the scientific basis for the development of studies and public policies addressing this issue. The work involved over 1300 experts worldwide who, in collaboration, produced a scientific-technical report containing five volumes whose findings revealed declines in biodiversity and cultural services, clean water (for human consumption and production purposes), air quality, and climate regulation (particularly at local and regional levels), among other factors.

The concept of ESs developed in the context of the MEA encompasses not only the benefits related to the environmental dimension of ecosystems, but also includes social and cultural aspects in building integration between man and nature. Drawing on previous studies [25,30], the MEA defined the concept of ESs as the benefits humans obtain from ecosystems and established four categories for assessing these services, namely: (a) support services (e.g., soil formation and nutrient cycling); (b) provision services (e.g., food, water, wood, and fuel); (c) regulation services (e.g., climate regulation, flood control, water treatment); and (d) cultural services (e.g., recreation, aesthetics, spirituality, and education).

All these categories are related to the concept of human well-being, defined in the report as the guarantee of material and non-material conditions which promote well-being, including safe and adequate means of living, food, shelter, clothing and access to goods, health and a healthy physical environment, and freedom of choice, all within a framework of balance between ecosystems and human needs.

\section{Materials and Methods}

\subsection{Methods}

A hybrid method of bibliometric analysis and in-depth reading of key articles was employed for the present study. 
The first phase of the review was performed using the bibliometric analysis method, a quantitative method involving statistical analysis of articles published and citations to measure their respective impacts. In situations involving a large volume of academic and scientific output, the bibliometric method is useful for providing a structured analysis of a large volume of information, allowing the researcher to gain a broader picture of a research area [31]. This phase was conducted using the Software RStudio (version 4.0.4) with the aid of the bibliometrix R-package and BiblioShiny app [32] to carry out a quantitative analysis of the articles retrieved from the WoS on-line database. The search terms, period, and inclusion criteria for the search are presented later.

After the quantitative analysis, which allowed trends, main authors, countries, and references addressing the theme to be identified, a second stage entailing a qualitative analysis was commenced. The twelve highest-impact articles were selected for in-depth reading based on the number of citations. The aim of this full examination was to determine whether the authors established a relationship between ESs and tackling climate change in the urban context, as well as to identify the method proposed by each publication. During screening of this second phase, the articles "Managing aquatic ecosystems and water resources under multiple stress-An introduction to the MARS project" by H. Gering and "Biogeochemical C and N cycles in urban soils" by K. Lorenz were excluded because they addressed highly specific aspects not directly related to urban issues.

\subsection{Data Sources and Treatment}

The WoS database was elected for the search, constituting one of the most recognized databases holding high quality standardized academic publications. In addition, this database is recommended for analyses conducted with the Bibliometrix R-package [32] The search protocol entailed 4 phases, as depicted in Figure 1. The first phase was devising the search strategy to be applied to the WoS database, involving selection of key words for mapping the research area and analysis of articles selected. The second phase involved research and data collection, employing the keywords "climate change" AND "ecosystem services" AND "urban planning". The search terms were applied to the fields "Title", "Abstract", and "Keywords" for the period spanning from 2000 to 2020, covering the following areas of knowledge: environmental sciences, environmental studies, ecology, urban studies, and regional urban planning. Phase 3 involved the analysis and treatment of data using the software tool RStudio (version 4.0.4) in conjunction with the Bibliometrix package. Lastly, phase 4 was performed, in which key articles from the literature were selected for more in-depth reading and critical analysis of results. 


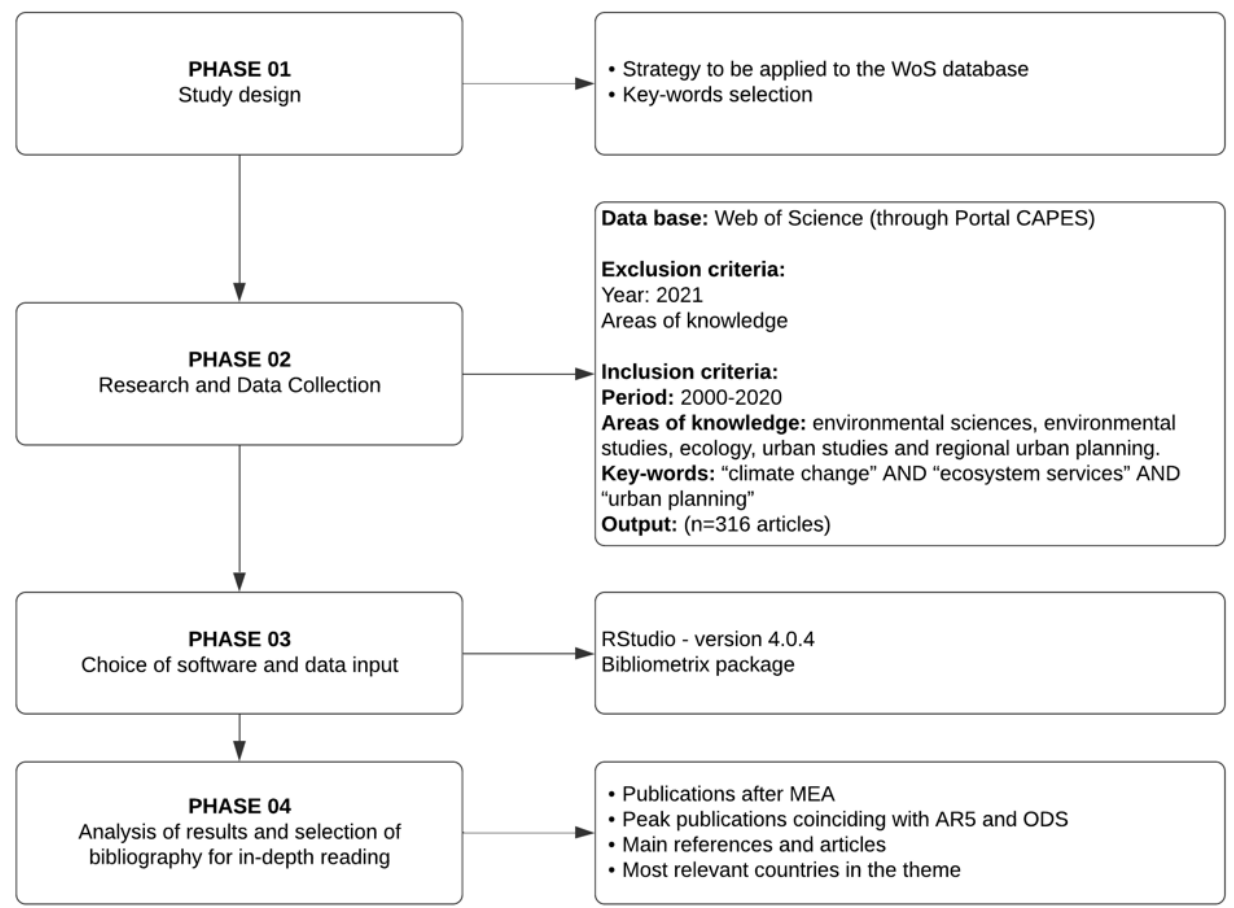

Figure 1. Search protocol. Prepared by authors.

\section{Results}

\subsection{Bibliometric Analysis}

The output of data collection after filtering yielded 316 articles (Supplementary Data). The graph below (Figure 2), depicting the data retrieved from the WoS database, clearly shows the growing academic-scientific interest in the topic. Interest in relation to urban areas surged after publication of the Fifth Report of the IPCC $[26,33]$ and the Sustainable Development Goals-SDG [34], which promoted the agenda of cities as a key element for sustainable development.

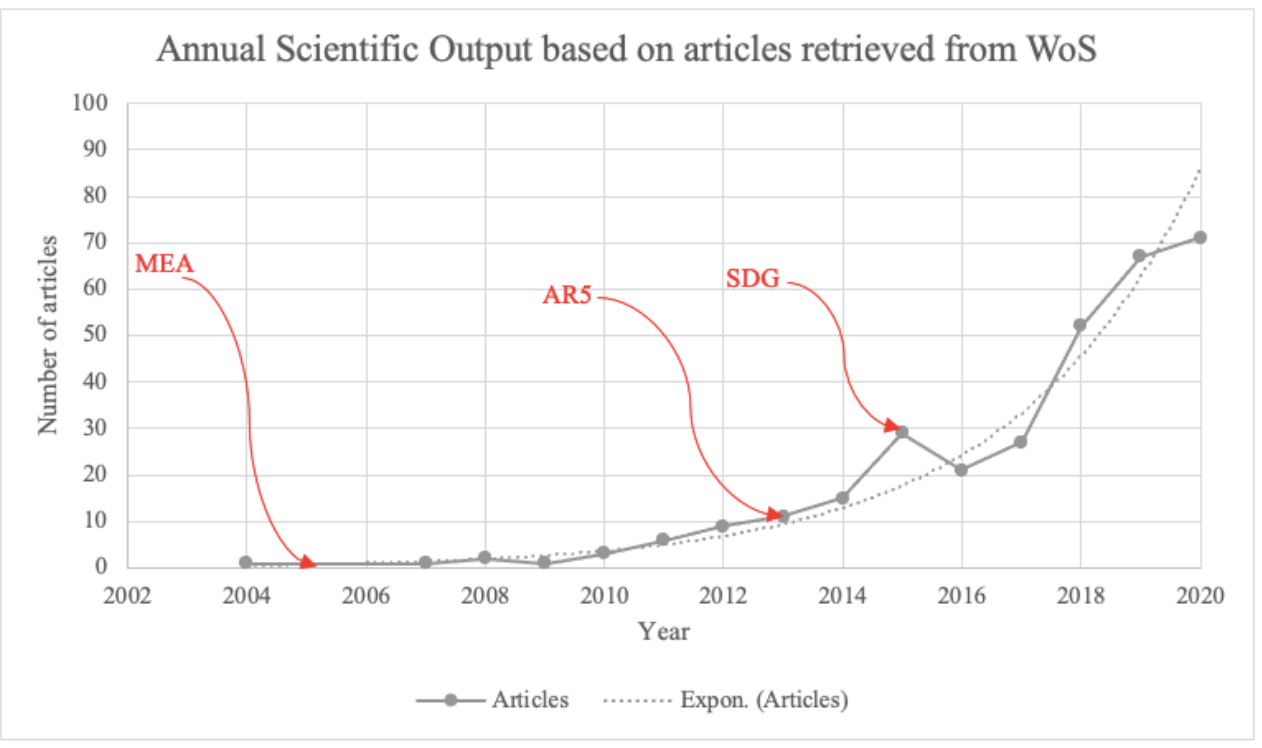

Figure 2. Annual scientific output (2000-2020). Source: produced by authors based on articles retrieved from WoS.

The main journals that published relevant articles in the search period were Sustainability (31), Landscape and Urban Planning (26), Ecological Indicators (18), Science of 
the Total Environment (17), and Land Use and Policy (14). The journal Landscape and Urban Planning ranked highest for number of local citations (1185), followed by Ecological Indicators (426), Urban Forestry and Urban Greening (371), and Ecosystem Services (356).

Regarding countries with the highest number of publications, the United States of America (USA) ranked top (189 articles), followed by China (134) and Germany (83), whereas for impact in terms of citations, the USA predominated (2025), followed by Germany (1192), Australia (936), and China (684) (Figure 3).

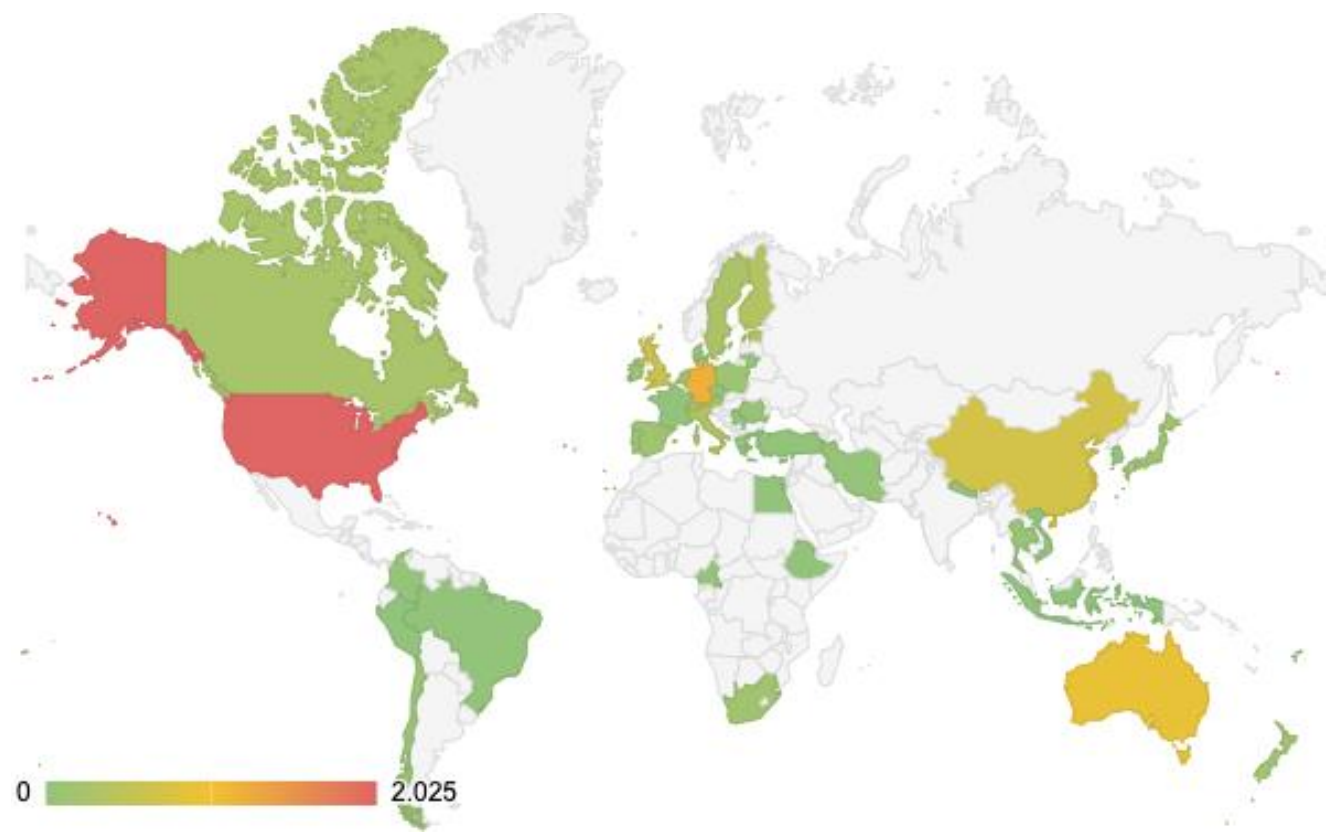

Figure 3. Most-cited countries. Source: produced by authors based on data from WoS processed by RStudio using the Bibliometrix package.

Figure 4 shows the relationship between the main references cited in the articles, the most prominent authors on the subject (based on impact of articles), and the most commonly used keywords. Interestingly, one of the most cited references on the database was the MEA, along with several seminal articles which provided the basis for this line of research, such as the 1997 article by Robert Costanza et al. in Nature [25].

Additionally, regarding the most-cited references involving application in urban areas, a number of these articles are seminal. These include articles by Per Bolund and Sven Hunhammar [23] and by Konstantinos Tzoulas [35], investigating the importance of ecosystem services in urban areas and their contributions to human well-being, the articles by Erik Gómez-Baggethunab and David Barton [36], classifying and assessing ecosystem services in urban areas, advocating the introduction of economic and non-economic evaluations of ecosystem services for the process of urban planning and decision-making, and the paper by De Groot et al. [37], whose investigation examined the challenges of integrating the concept of ecosystem services and values in landscape planning and decision-making.

The most prolific authors on the subject were Dagmar Haase (Humboldt UniversityGermany), Christine Wamsler (Lund University-Sweden), Stephan Pauleit (Technical University of Munich-Germany), Davide Geneletti (Trento University-Italy), and Francisco J. Escobedo (University of Florida-USA). There was major interest in the topic among EU countries, particularly Germany (Figure 5). Latin American and Caribbean countries, however, had low output and few citations on the subject. 


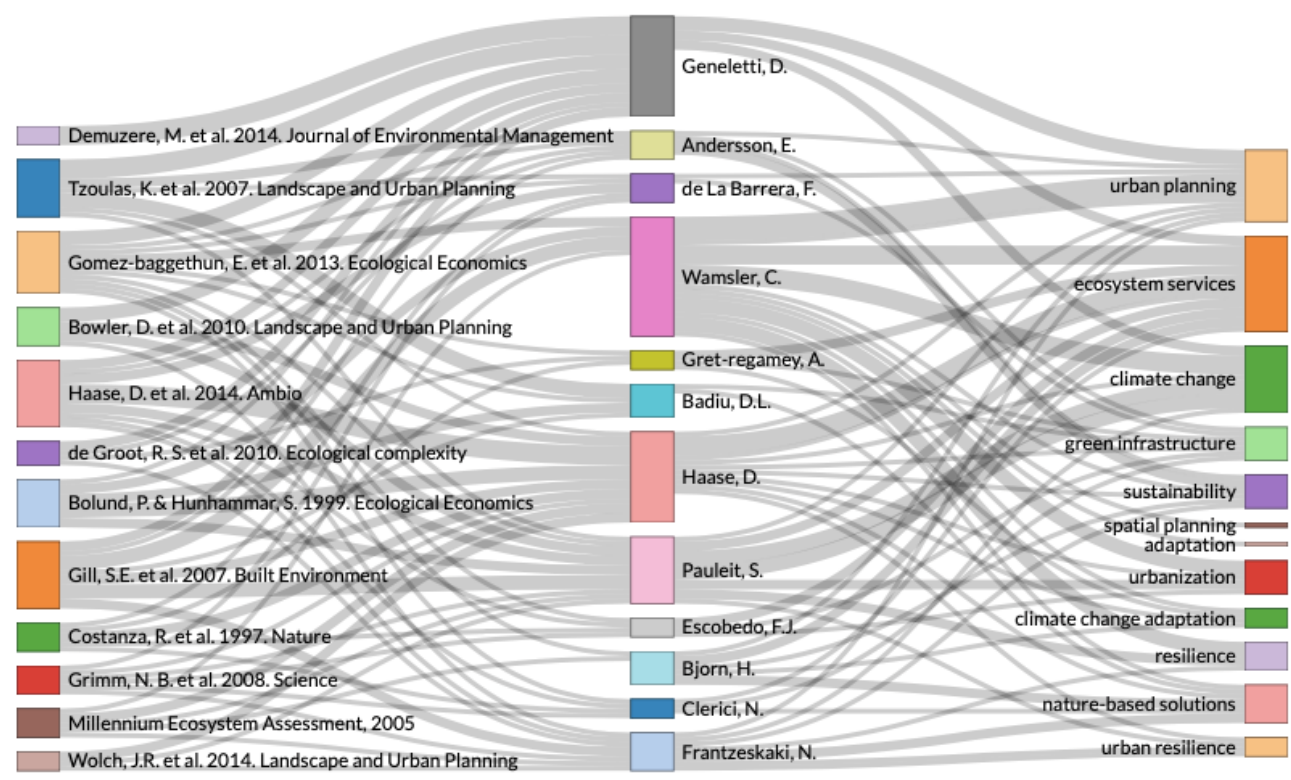

Figure 4. A three-field plot (Sankey diagram) showing the relationship among most-cited references, highest-impact authors, and most commonly used keywords. Source: produced by authors based on data from WoS processed by RStudio using the Bibliometrix package.

Top 10 Countries
(production)
1. Usa
2. China
3. Germany
4. Sweden
5. Uk
6. Italy
7. Australia
8. Netherlands
9. Canada
10. Switzerland

Most prolific authors
1. Haase D
2. Wamsler C.
3. Pauleit S.
4. Geneletti D.
5. Escobedo F. J.
6. Gret-regamey A.
7. Andersson E.
8. Badiu D.
9. Bjorn H.
10. Clerici N.

Most relevant Journals
1. Sustainability
2. Landscape And Urban Planning
3. Ecological Indicators
4. Science Of The Total Environment
5. Land Use Policy
6. Urban Forestry \& Urban Greening
7. Ecosystem Services
8. Journal Of Environmental Management
9. Cities
10. Ecology And Society

Figure 5. Relationship among most-cited references, most-prolific authors, and most commonly used keywords. Source: produced by authors based on data from WoS processed by Rstudio using the Bibliometrix package.

Brazil ranked 33rd in the most-cited countries, with only 13 citations. Few Brazilian authors addressed ecosystem-based adaptation from an urban planning perspective in indexed journals, where studies instead tended to center on the areas of biology and conservation and on the Amazon Forest. However, the author Fabio Scarano [5] published a key article providing an overview of the concept of Ecosystem-Based Adaptation, highlighting its potential for adaptation to climate change in developing countries, including urban and peri-urban areas.

Figure 4 shows the recurrent key words, representing an extended group of the primary terms searched, namely: "ecosystems services", "climate change" and "urban planning", to include "adaptation", "adaptation to climate change", "resilience", and "green infrastructure", illustrating that the terms searched involve different lines of research which seek to reconcile nature and the city with respect to adaptation.

\subsection{Review of Articles with Highest Impact}

With the aim of determining whether the authors established a relationship between ESs and coping with climate change in the urban context, and to analyse the method 
reported in each publication, the twelve highest-impact articles were selected for more in-depth reading.

The articles analysed were of three main methodological types: (1) literature review [9,10,38-40]; (2) case studies-qualitative analysis [6,12]; and (3) analyses/or scenarios with Geographic Information System (GIS) software [11,41-43].

The articles pointed to the need for creating a new perspective for urban planning which puts human well-being center stage and adopts an interdisciplinary approach, involving a range of different societal actors and professionals from various fields of knowledge that promote integration of research, practice, and public policies. Several barriers were identified by different authors, such as the need for new models of governance and the incorporation of social aspects in studies on the subject, and the conducting of future studies which can provide scientific evidence of causality between ESs and adaptation to climate change.

Most articles showed a relationship between ESs and adaptation to climate change using different scales and approaches (see Table 1). Some articles performed analyses based on the ESs concept, while others mentioned ESs but centered on related operational concepts, such as Green Infrastructure (GI), Nature-based Solutions (NbS), and Ecosystembased Adaptation (EbA).

Table 1. Analysis of most-relevant articles selected from literature review.

\section{Relationship between Ecosystem Services and Tackling Climate Change in the Urban Context Addressed? \\ Method Employed?}

Partially. The study made an association between ESs and adaptation to climate change but focused more on health-related benefits in the form of human well-being. The authors

SANDIFER, P.A., 2015 [38] highlighted the need for a new vision of urban planning centered on human well-being and a fresh interdisciplinary approach.

Yes. The study reported a direct relationship between ESs provided by green infrastructure and adaptation to climate change with an emphasis on mitigating high temperatures in urban areas, citing other complementary benefits.
Review of the literature focused on

peer-reviewed high-relevance articles. Given the interdisciplinary nature of the subject matter, articles from different knowledge areas were reviewed (ecology and ecosystem services, public health, biomedicine, urban planning, and psychology, among others).

Quantitative assessment with use of GIS software combining census/demographic data, temperature, land use, and social vulnerability.
Yes. The article noted that green areas/infrastructure promote ecosystem services that yield biophysical and psychological benefits, while also helping

DEMUZERE, M., 2014 [9] toward adaptation to and mitigation of climate change. The categories showing greatest evidence were: health and restoration benefits, social and individual response capacity, and education; flood reduction, improvement in water quality, and reduction in $\mathrm{CO}_{2}$.

Yes. The authors argued cities are socioecological systems and that promoting ecosystem services in urban areas via green infrastructure, together with the participative process, increases resilience and adaptation to the challenges of climate change.
Systematization of evidence found in the literature regarding benefits of urban green infrastructure for adaptation to and mitigation of climate change on three different scales.

Review of the literature, description of tools supporting application of green infrastructure, and selecting strategies of engaging the community in the planning process. 
Table 1. Cont.

\section{Relationship between Ecosystem Services and Tackling Climate Change in the Urban Context Addressed?}

Yes. The authors showed that the ESs approach provides an opportunity for urban region

planning from a more ecological and

NIEMELA, J., 2010 [6] sustainable perspective and that conservation of ecosystems and urban planning can mitigate the effects of climate change on urban regions.

Yes. The authors, however, used the NbS concept, pointing to the benefits of ecosystem-based solutions for adaptation and mitigation of climate change in the context of cities. The authors recognized the $\mathrm{NbS}$ concept is linked to other concepts involving ecology aspects proposing solutions for cities, such as "green infrastructure" and "ecosystem-based adaptation", among others.

Partially. The article did not make a direct reference to the climate change issue, but HAASE, D., 2012 [43] touches on the role of ESs in urban regions for improving local climatic conditions, potential for the areas of recreation and biodiversity, food production, and carbon absorption.
MATTHEWS, T., 2015 [40]

GILL, S.E., 2008 [12]
Yes. The authors, however, focused on the concept of green infrastructure.

\section{Method Employed?}

Qualitative assessment on how the ESs approach has been used in planning and conservation of green areas based on the case of Finland.

Qualitative assessment based on a Workshop involving experts from different disciplines addressing $\mathrm{NbS}$ and their relationship with adaptation to and mitigation of climate change. The workgroups discussed: (1) indicators for measuring the effectiveness of

$\mathrm{NbS}$ for mitigation of and adaptation to climate change and associated benefits; (2) gaps in knowledge on the effectiveness of $\mathrm{NbS}$ in cities; (3) barriers to implementing $\mathrm{NbS}$; and (4) opportunities for facilitating the action of $\mathrm{NbS}$.

A quali-quantitative assessment using GIS software drawing on land cover data (1990, 2000, and 2006) and ES indicators of local climate regulation, above-ground carbon storage, biodiversity potential, food production, and recreation potential.

Qualitative method of reviewing the literature and conducting semi-structured interviews with urban planners from academic and both public and private sectors engaged in climate change, land planning, and green infrastructure.

Yes. The results highlighted ESs that benefit the local context and help promote adaptation to climate change, but also revealed ecosystem "disservices" at a local scale, such as increasing pollen and allergies.

No. The article provided a critical analysis of the urban resilience concept, associated with climate change, showing its tensions, conflicts, and trade-offs.

Partially. The article cited the potential of ESs and green infrastructure in the context of climate change, but its scope centered on methodologies for characterizing urban areas (land cover, more accurate mapping of green areas) to support plans and projects related to the issue.

No. The articles involved a model for assessing and valuing ESs for building scenarios to aid GRET-REGAMEY, A., 2008 [41] decision-makers in visualizing impacts. The authors made an association between ESs and local benefits, but not with climate change.
Qualitative method of revising the literature based on a matrix of ecosystem services focused on urban areas at a local scale.

Qualitative method with scenario modelling using GIS software.

Urban morphology-type mapping and land surface analysis to support assessments of ESs and aid green infrastructure planning and strategies for adaptation to climate change based on the case of a region in Manchester (UK).

Scenario building, process of modelling, and economic evaluation, all integrated in GIS software, followed by building scenarios for assessing impacts. 
Corroborating the broad conceptual view in approaches to the topic, Figure 6 shows a growing variety in trend-topics over the years. In 2011, articles were more centered on urban form, in 2014 on the environment dimension, whereas in 2015 articles tended to focus on indicators. Between 2016 and 2020, the topics were broader, with emphasis on the issue of climate change (temperature, vulnerability, impacts, and potential impacts), adaptation (adaptation to climate change, adaptation, and resilience), cities, and ecosystem services.

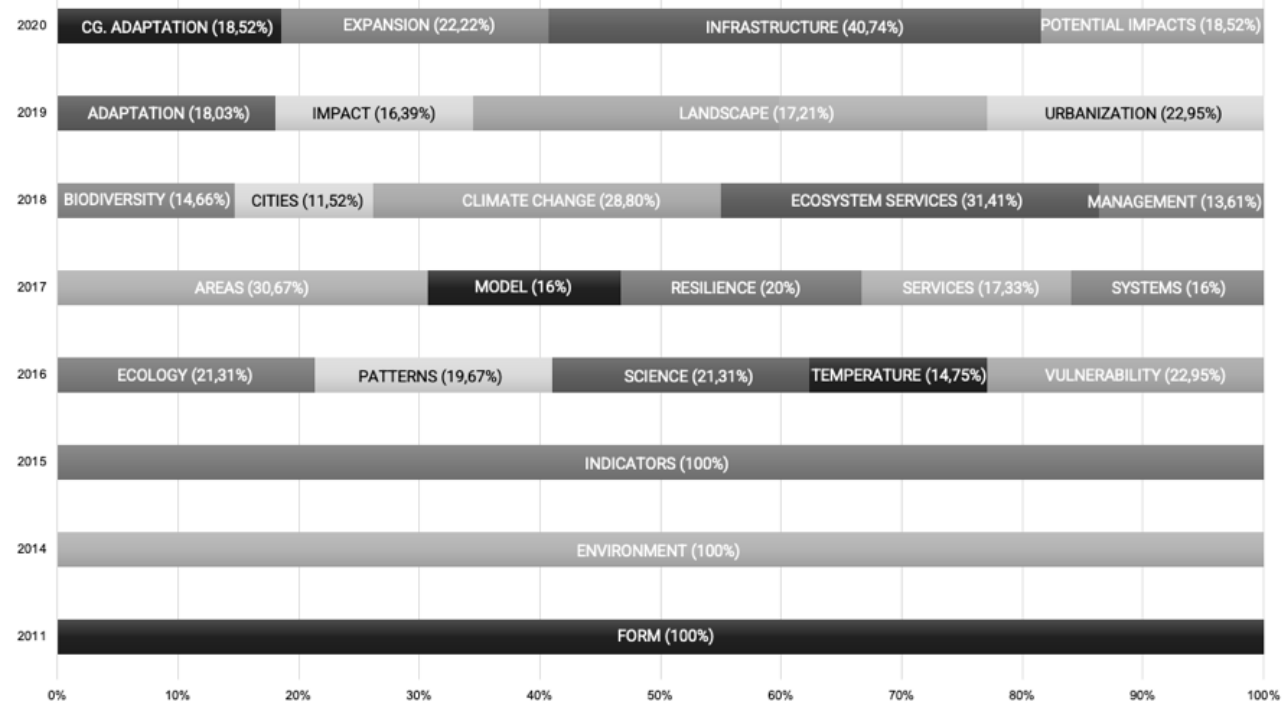

Figure 6. Topics most addressed in articles published between 2011 and 2020. Source: produced by authors based on data from WoS processed by Rstudio using the Bibliometrix package.

\section{Discussion}

Based on the results of the bibliometric review and qualitative analysis of the articles selected for in-depth reading, this section presents a discussion of the findings underpinning the involvement of interdisciplinarity in linking ESs research to urban planning (4.1.), the use of different operational concepts that emerged from this research area for urban planning (4.2.), and reflections on the challenges for future studies conducted on this subject (4.3).

\subsection{Scientific Interest and Interdisciplinarity}

According to Davide Geneletti [8] and Christian Kull [27], the concept of ecosystem services has been attracting growing interest in the scientific milieu and in the arena of policymaking over the last 20 years. Corroborating this trend, the results of the present literature review showed increasing scientific-academic interest in the concept with relation to adaptation to climate change in urban areas.

It is noteworthy, however, that the concept first emerged in the discussion of the theory of conservation in the 1981 book titled "Extinction; the causes and consequences of the disappearance of species" [44], and was also widely cited in a number of disciplines from the 1990s onwards following the publication of the book titled "Nature's services: societal dependence on natural ecosystems" by Gretchen Daily [30] and of the article "The value of the world's ecosystem services and natural capital" by Robert Costanza et al. [25] in the journal Nature. These two publications, together with their authors and research groups, proved pivotal in creating the MEA, which elevated the concept of ecosystem services to a global level and helped shape environmental agendas and public policies [27].

The MEA report represented a significant milestone for sustainable development by introducing a more complex view of ecological and social systems into the international debate and by considering environmental problems as relational rather than sectoral. The aim of the report was not only to carry out an assessment of the state of biodiversity loss of the 
planet, but to elucidate the relationship among ESs, human well-being, and development toward an integrated view incorporating multiple dimensions and different actors.

Besides confirming the interdisciplinary nature of the concept, the results of this review revealed a trend toward interdisciplinarity in research on the subject, given most of the articles reviewed involved several authors, and the leading authors had different areas of expertise, such as urbanism, landscaping, biology, economics, and geography, among others. It is important to point out that, although the review showed the collaboration of authors from various fields of knowledge in producing the articles and contributing to this trend towards interdisciplinarity, the literature reviewed in-depth also revealed limits to this interdisciplinarity and difficulties implementing the concepts based on the use of ESs to climate change adaptation in urban areas, as is further discussed in the ensuing sections.

\subsection{Research Approaches in the Urban Environment Involving Different Evaluation Methods}

By discussing and comparing the graph of annual Scientific Output (Figure 2) against the figure depicting trend-topics (Figure 6), it is evident that in the areas of Urban Planning, the concept involved contributions in the field of theory and in devising lines of research linking the ESs concept with adaptation to climate change in urban environments. Indeed, the integration between city and nature, or between natural and built environments, is not exactly new in city planning. There are centuries-old theoretical frameworks and practices in the area of urbanism and urban landscapes that have sought this kind of integration, for example, the renowned studies by Ian McHarg [45], Patrick Geddes and Ebenezer Howard [46]. On the other hand, the 20th century was marked by a rupture between the city and nature [47].

Research work seeking to integrate natural and built environments culminated in different lines of theory and practice in the field of urban planning and landscape. The ESs concept, particularly owing to its integrating and interdisciplinary concept defined in the MEA, influenced the creation of key research approaches in contemporary urbanism, as illustrated in the time-line below (Figure 7).

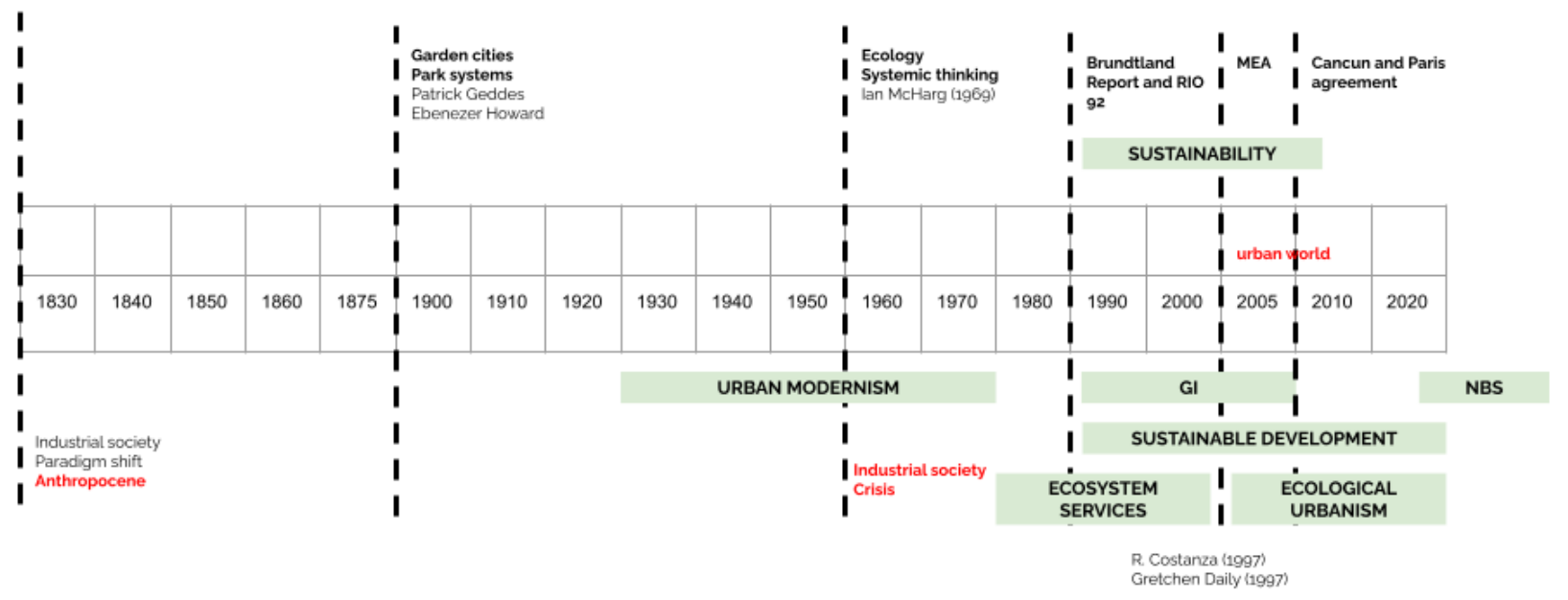

Figure 7. Discussion outcome: Time-line conceptualizing the issues of climate change and Ecosystem Services in Urban Planning and highlighting the major milestones. Source: produced by author.

These approaches are aimed at exploiting the benefits provided by nature in the planning process and reconnecting cities and the biosphere, giving rise to the concepts addressed in the articles reviewed, such as Ecosystem-based Adaptation (EbA), Green Infrastructure (GI), and Nature-based solutions (NbS).

These overlapping concepts are important in the scientific-academic debate and also in the devising of public policies. According to O'Sullivan, Mell, and Clement [16], the differences between $\mathrm{NbS}$ and other similar concepts created previously remain unclear. Pauleit et. al. [14] proposed systematizing these concepts in the urban planning sphere 
based on a literature review, attributing some definitions to each concept while acknowledging their overlaps (see Table 2).

In this regard, within the area of urban planning, the concepts of Ecosystem Services (ESs), Green Infrastructure (GI), Ecosystem-based Adaptation (EbA), and Nature-based solutions ( $\mathrm{NbS}$ ) overlap in many ways yet differ with regard to the clarity of their definitions and practical applicability in the urban planning process. For instance, the Green Infrastructure (GI) concept is the most consolidated as regards application, whereas Ecosystem Services has a more well-established definition over a longer period, but in the urban planning field commonly requires other concepts to allow its wider implementation. While all these concept address climate change to some degree, $\mathrm{EbA}$ and $\mathrm{NbS}$ are more centered on strategies for adaptation to climate change [14].

The pattern that seems to underlie these concepts applied to urban planning is the incorporation of nature as a central element for the adaptation of cities in the face of climate change, as part of the quest for (re)connection between human needs and the capacity of the biosphere. This interpretation closely resembles the concept of resilience from a socialecological perspective, based on the notion that building resilience not only means adapting or responding to crisis and change, but also to transforming social-ecological systems to offer greater sustainability, where resilience is seen as a transformational capacity, involving new ways of planning cities and of conceiving the relationship between the natural and built environments [48,49].

\subsection{Challenges for Future Studies}

With respect to urban planning, the approaches involving the use of benefits provided by nature as an element of strategies for adaptation to climate change have been developed based on the notion of the city as a new-and complex-ecosystem, in an effort to better understand the interactions between the systems needed for cities and ecosystems, the natural and built environments, and to work together toward the goal of achieving human well-being $[24,50]$.

The interaction of the concept of ESs in the urban planning process yields benefits to further the concept of developing more sustainable cities. This concept can help bring together scientific knowledge and evidence from different areas of knowledge and allow the creation of scenarios that embrace multiple dimensions and provide a balance of powers in decision-making [8]. However, the complexity of urban and metropolitan areas, conflicting legislation, interests, and agendas, on top of uncertainties, poses a major challenge in applying these models to solve real-world problems.

Despite the promising nature and growing number of publications, numerous challenges and questions remain, particularly concerning models of governance (balance of powers and participation of different actors) and implementation to promote city transformation, in addition to the need for further scientific studies exploring ecosystem services and disservices in tackling climate change, where many studies focus on correlation as opposed to causality. The areas for which most evidence is available in the articles reviewed include regulation services (e.g., regulation of climate and floods, water treatment, and $\mathrm{CO}_{2}$ absorption).

Besides research with a focus on causality, the complexity of urban systems requires future studies to approach cities as complex and diverse new ecosystems which have resulted from a process of human-nature co-evolution [51]. As outlined earlier, from a socialecological perspective, the construction of resilient and sustainable urban environments involves the transformation of urban systems into a connection between human needs and biosphere capacity. Future studies should consider ways of integrating city and nature, pooling efforts to ensure effective communication of the potential paths ahead to foster not only adaptation and mitigation in the cities, but their potential transformative capacities towards this ecological perspective, along with the inherent pros, cons and uncertainties. 
Table 2. Comparison of the concepts of Nature-based Solutions, Ecosystem-Based Adaptation, Green Infrastructure, and Ecosystem Services.

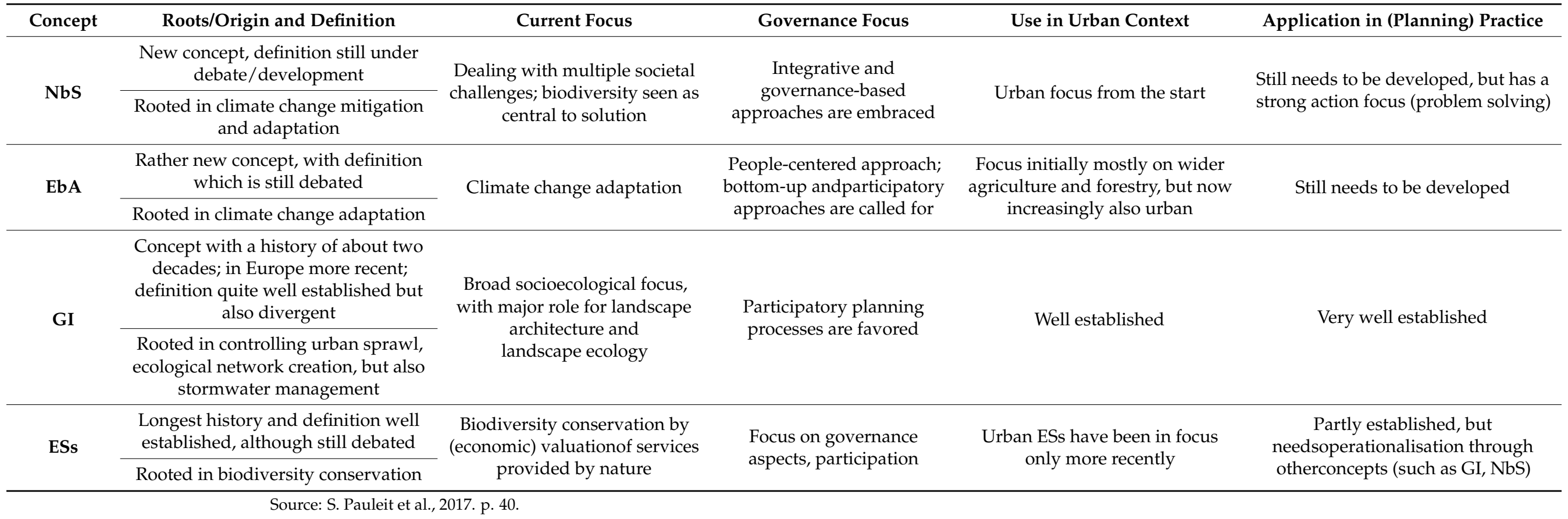




\section{Conclusions}

There is growing scientific interest in the relationship between ecosystem services and adaptation to climate change. The ESs concept has made a major contribution in the area of urban planning, integrating different areas of knowledge to help weigh the importance of the benefits that humans can obtain from nature and establish new models of development and planning in cities and approaches promoting adaptation to climate change.

The key novel feature of ESs is their systemic view, which treats the issue of sustainability not as a mere environmental problem, but a complex phenomenon. The concept incorporates cultural, social, and economic aspects, showing a shift in paradigm toward sustainability entails multiple dimensions that call for an interdisciplinary approach, embracing different actors and areas of knowledge.

This approach, interdisciplinary in nature, encompasses different research areas and methods, including in the area of urbanism, and underpins the concepts of Green Infrastructure, Ecosystem-based Adaptation, and the more-recent concept of Nature-based solutions. Although some authors associated ESs with economic assessments of ecosystems, there are different methods of evaluation, both economic and non-economic. In the area of urban planning, biophysical, sociocultural, and economic methods prevail, where these can be combined and integrated to achieve the required objective.

Despite important contributions and advances, several challenges and opportunities remain for future studies investigating ESs and adaptation to climate change in urban environments. More specifically, there is a need for further studies mapping causal relationships and benefits from nature to formulate solutions for adaptation that incorporate social aspects and new models of governance that ensure effective participation and a balance of powers to help promote the goal of collective well-being, as well as the transformation of urban systems to have greater resilience from a social-ecological perspective.

Supplementary Materials: The following supporting information can be downloaded at: https: //www.mdpi.com/article/10.3390/su14042391/s1.

Author Contributions: Conceptualization, A.L.M. and A.T.B.A.; methodology, A.L.M.; software, A.L.M.; validation, A.L.M., A.T.B.A. and J.S.; writing—original draft preparation, A.L.M. and A.T.B.A.; writing-review A.L.M., A.T.B.A. and J.S.; supervision, A.T.B.A. and J.S. All authors have read and agreed to the published version of the manuscript.

Funding: This study was financed in part by the Coordenação de Aperfeiçoamento de Pessoal de Nível Superior-Brasil (CAPES)-Finance Code 001 and Programa de Excelência Acadêmica (Process 23038.006765/2021-64) - and Deutscher Akademischer Austauschdienst (DAAD).

Institutional Review Board Statement: Not applicable.

Informed Consent Statement: Not applicable.

Data Availability Statement: We added the data used to the Supplementary Materials.

Acknowledgments: The authors are grateful to CAPES PROEX; CAPES PRINT (Mackenzie Presbyterian University International Project), DAAD and CNPq for making this work possible.

Conflicts of Interest: The authors declare no conflict of interest.

\section{References}

1. United Nations World Urbanization Prospects: The 2018 Revision; Online Edition; United Nations: New York, NY, USA, 2019; Available online: https:/ / www.un.org/development/desa/publications/2018-revision-of-world-urbanization-prospects.html (accessed on 22 December 2021).

2. $\quad$ Core Writing Team; Pachauri, R.K.; Meyer, L.A. (Eds.) IPCC, 2014: Climate Change 2014: Synthesis Report. Contribution of Working Groups I, II and III to the Fifth Assessment Report of the Intergovernmental Panel on Climate Change; IPCC: Geneva, Switzerland; p. 151. 
3. IPCC Global Warming of $1.5^{\circ} \mathrm{C}$. An IPCC Special Report on the Impacts of Global Warming of $1.5^{\circ} \mathrm{C}$ above Pre-Industrial Levels and Related Global Greenhouse Gas Emission Pathways, in the Context of Strengthening the Global Response to the Threat of Climate Change, Sustainable Development, and Efforts to Eradicate Poverty; Masson-Delmotte, V.; Zhai, P.; Pörtner, H.-O.; Roberts, D.; Skea, J.; Shukla, P.R.; Pirani, A.; Moufouma-Okia, W.; Péan, C.; Pidcock, R.; et al. (Eds.) IPCC: Geneva, Switzerland, 2018.

4. Kabisch, N.; Frantzeskaki, N.; Pauleit, S.; Naumann, S.; Davis, M.; Artmann, M.; Haase, D.; Knapp, S.; Korn, H.; Stadler, J.; et al. Nature-based solutions to climate change mitigation and adaptation in urban areas: Perspectives on indicators, knowledge gaps, barriers, and opportunities for action. Ecol. Soc. 2016, 21(2), 39. [CrossRef]

5. Scarano, F. Ecosystem-based adaptation to climate change: Concept, scalability and a role for conservation science. Perspect. Ecol. Conserv. 2017, 15, 65-73. [CrossRef]

6. Niemelä, J.; Saarela, S.-R.; Söderman, T.; Kopperoinen, L.; Yli-Pelkonen, V.; Väre, S.; Kotze, D.J. Using the ecosystem services approach for better planning and conservation of urban green spaces: A Finland case study. Biodivers. Conserv. 2010, 19, 3225-3243. [CrossRef]

7. Jiang, Y.; Hou, L.; Shi, T.; Gui, Q. A Review of Urban Planning Research for Climate Change. Sustainability 2017, 9, 2224. [CrossRef]

8. Geneletti, D.; Cortinovis, C.; Zardo, L.; Esmail, B.A. Planning for Ecosystem Services in Cities; Springer Briefs in Environmental Science; Springer International Publishing: Cham, Switzerland, 2020; ISBN 978-3-030-20023-7.

9. Demuzere, M.; Orru, K.; Heidrich, O.; Olazabal, E.; Geneletti, D.; Orru, H.; Bhave, A.G.; Mittal, N.; Feliu, E.; Faehnle, M. Mitigating and adapting to climate change: Multi-functional and multi-scale assessment of green urban infrastructure. J. Environ. Manag. 2014, 146, 107-115. [CrossRef]

10. Salmond, J.A.; Tadaki, M.; Vardoulakis, S.; Arbuthnott, K.; Coutts, A.; Demuzere, M.; Dirks, K.N.; Heaviside, C.; Lim, S.; MacIntyre, H.; et al. Health and climate related ecosystem services provided by street trees in the urban environment. Environ. Health 2016, 15, 95-111. [CrossRef]

11. Norton, B.A.; Coutts, A.M.; Livesley, S.J.; Harris, R.J.; Hunter, A.M.; Williams, N.S.G. Planning for cooler cities: A framework to prioritise green infrastructure to mitigate high temperatures in urban landscapes. Landsc. Urban Plan. 2015, 134, 127-138. [CrossRef]

12. Gill, S.E.; Handley, J.F.; Ennos, A.R.; Pauleit, S.; Theuray, N.; Lindley, S.J. Characterising the urban environment of UK cities and towns: A template for landscape planning. Landsc. Urban Plan. 2008, 87, 210-222. [CrossRef]

13. Geneletti, D.; Cortinovis, C.; Zardo, L.; Esmail, B.A. Reviewing Ecosystem Services in Urban Climate Adaptation Plans. In Planning for Ecosystem Services in Cities; Springer International Publishing: Cham, Switzerland, 2020; pp. 21-30. [CrossRef]

14. Pauleit, S.; Zölch, T.; Hansen, R.; Randrup, T.B.; van den Bosch, C.K. Nature-Based Solutions and Climate Change-Four Shades of Green; Springer: Cham, Switzerland, 2017; ISBN 978-3-319-56091-5.

15. Nesshöver, C.; Assmuth, T.; Irvine, K.N.; Rusch, G.M.; Waylen, K.A.; Delbaere, B.; Haase, D.; Jones-Walters, L.; Keune, H.; Kovacs, E.; et al. The science, policy and practice of nature-based solutions: An interdisciplinary perspective. Sci. Total Environ. 2017, 579, 1215-1227. [CrossRef]

16. O'Sullivan, F.; Mell, I.; Clement, S. Novel Solutions or Rebranded Approaches: Evaluating the Use of Nature-Based Solutions (NBS) in Europe. Front. Sustain. Cities 2020, 2, 572527. [CrossRef]

17. Chatzimentor, A.; Apostolopoulou, E.; Mazaris, A.D. A review of green infrastructure research in Europe: Challenges and opportunities. Landsc. Urban Plan. 2020, 198, 103775. [CrossRef]

18. Brink, E.; Aalders, J.T.; Ádám, D.; Feller, R.; Henselek, Y.; Hoffmann, A.; Ibe, K.; Matthey-Doret, A.; Meyer, M.; Negrut, N.L.; et al Cascades of green: A review of ecosystem-based adaptation in urban areas. Glob. Environ. Chang. 2016, 36, 111-123. [CrossRef]

19. Matsler, A.M.; Meerow, S.; Mell, I.C.; Pavao-Zuckerman, M.A. A 'green' chameleon: Exploring the many disciplinary definitions, goals, and forms of "green infrastructure". Landsc. Urban Plan. 2021, 214, 104145. [CrossRef]

20. Guerry, A.D.; Polasky, S.; Lubchenco, J.; Chaplin-Kramer, R.; Daily, G.C.; Griffin, R.; Ruckelshaus, M.H.; Bateman, I.J.; Duraiappah, A.; Elmqvist, T.; et al. Natural capital and ecosystem services informing decisions: From promise to practice. Proc. Natl. Acad. Sci. USA 2015, 112, 7348-7355. [CrossRef] [PubMed]

21. Tan, P.Y.; Zhang, J.; Masoudi, M.; Alemu, J.B.; Edwards, P.J.; Grêt-Regamey, A.; Richards, D.R.; Saunders, J.; Song, X.P.; Wong, L.W. A conceptual framework to untangle the concept of urban ecosystem services. Landsc. Urban Plan. 2020, 200, 103837. [CrossRef]

22. MEA. Ecosystems and Human Wellbeing; Island Press: Washington, DC, USA, 2005; ISBN 9781610914840.

23. Bolund, P.; Hunhammar, S. Ecosystem services in urban areas. Ecol. Econ. 1999, 29, 293-301. [CrossRef]

24. Gómez-Baggethun, E.; Gren, Å.; Barton, D.N.; Langemeyer, J.; McPhearson, T.; O’Farrell, P.; Andersson, E.; Hamstead, Z.; Kremer, P. Urban Ecosystem Services. In Urbanization, Biodiversity and Ecosystem Services: Challenges and Opportunities; Springer: Dordrecht, The Netherlands, 2013; pp. 175-251.

25. Costanza, R.; d'Arge, R.; de Groot, R.; Farber, S.; Grasso, M.; Hannon, B.; Limburg, K.; Naeem, S.; O’Neill, R.V.; Paruelo, J.; et al. The value of the world's ecosystem services and natural capital. Nature 1997, 387, 253-260. [CrossRef]

26. Revi, A.; Satterthwaite, D.E.; Aragón-Durand, F.; Corfee-Morlot, J.; Kiunsi, R.B.R.; Pelling, M.; Roberts, D.C.; Solecki, W.; Balbus, J.; Cardona, O.D.; et al. Urban Areas. Adapt. Vulnerability Part A Glob. Sect. Asp. 2015, 535-612. [CrossRef]

27. Kull, C.; de Sartre, X.A.; Castro-Larrañaga, M. The political ecology of ecosystem services. Geoforum 2015, 61, 122-134. [CrossRef]

28. Martins, R.D.; Ferreira, L.d.C. Uma Revisão Crítica Sobre Cidades e Mudança Climática: Vinho Velho Em Garrafa Nova Ou Um Novo Paradigma de Ação Para a Governança Local? Rev. Adm. Pública 2011, 45, 611-641. [CrossRef] 
29. Jacobi, P.R.; Sinisgalli, P.A.D.A. Governança ambiental e economia verde. Cien. Saude Colet. 2012, 17, 1469-1478. [CrossRef] [PubMed]

30. Daily, G.C. Nature's Services. Societal Dependence on Natural Ecosystems; Island Press: Washington, DC, USA, 1997.

31. Moral-Muñoz, J.A.; Herrera-Viedma, E.; Santisteban-Espejo, A.; Cobo, M.J. Software tools for conducting bibliometric analysis in science: An up-to-date review. Prof. Inf. 2020, 29, e290103. [CrossRef]

32. Aria, M.; Cuccurullo, C. bibliometrix: An R-tool for comprehensive science mapping analysis. J. Infometr. 2017, 11, 959-975. [CrossRef]

33. IPCC. Climate Change 2014: Mitigation of Climate Change. Contribution of Working Group III to the Fifth Assessment Report of the Intergovernmental Panel on Climate Change; Edenhofer, O., Pichs-Madruga, R., Sokona, Y., Farahani, E., Kadner, S., Seyboth, K., Adler, A., Baum, I., Brunner, S., Eickemeier, P., et al., Eds.; Cambridge University Press: Cambridge, UK, 2014 ; ISBN 9781107654815.

34. UN. Transforming Our World: The 2030 Agenda for Sustainable Development; UN: New York, NY, USA, 2015.

35. Tzoulas, K.; Korpela, K.; Venn, S.; Yli-Pelkonen, V.; Kaźmierczak, A.; Niemela, J.; James, P. Promoting ecosystem and human health in urban areas using Green Infrastructure: A literature review. Landsc. Urban Plan. 2007, 81, 167-178. [CrossRef]

36. Gómez-Baggethun, E.; Barton, D.N. Classifying and valuing ecosystem services for urban planning. Ecol. Econ. 2012, 86, 235-245. [CrossRef]

37. De Groot, R.S.; Alkemade, R.; Braat, L.; Hein, L.; Willemen, L. Challenges in integrating the concept of ecosystem services and values in landscape planning, management and decision making. Ecol. Complex. 2010, 7, 260-272. [CrossRef]

38. Sandifer, P.A.; Sutton-Grier, A.; Ward, B.P. Exploring connections among nature, biodiversity, ecosystem services, and human health and well-being: Opportunities to enhance health and biodiversity conservation. Ecosyst. Serv. 2015, 12, 1-15. [CrossRef]

39. Lovell, S.T.; Taylor, J.R. Supplying urban ecosystem services through multifunctional green infrastructure in the United States. Landsc. Ecol. 2013, 28, 1447-1463. [CrossRef]

40. Matthews, T.; Lo, A.; Byrne, J. Reconceptualizing green infrastructure for climate change adaptation: Barriers to adoption and drivers for uptake by spatial planners. Landsc. Urban Plan. 2015, 138, 155-163. [CrossRef]

41. Grêt-Regamey, A.; Bebi, P.; Bishop, I.; Schmid, W.A. Linking GIS-based models to value ecosystem services in an Alpine region. J. Environ. Manag. 2008, 89, 197-208. [CrossRef]

42. Meerow, S.; Newell, J.P. Urban resilience for whom, what, when, where, and why? Urban Geogr. 2019, 40, 309-329. [CrossRef]

43. Haase, D.; Schwarz, N.; Strohbach, M.; Kroll, F.; Seppelt, R. Synergies, Trade-offs, and Losses of Ecosystem Services in Urban Regions: An Integrated Multiscale Framework Applied to the Leipzig-Halle Region. Germany. Ecol. Soc. 2012, 17(3), 22. [CrossRef]

44. Ehrlich, P.; Ehrlich, A. Extinction: The Causes and Consequences of the Disappearance of Species; Random House: New York, NY, USA, 1981.

45. McHarg, I.L. Design with Nature; American Museum of Natural History: New York, NY, USA, 1969 ; ISBN 0385021429.

46. Howard, E. Garden Cities of Tomorrow; MIT Press: Cambridge, MA, USA, 1965; Volume 23, ISBN 0262580020.

47. Herzog, C.P. Cidades Para Todos; Mauad Editora Ltda: Rio de Janeiro, Brazil, 2013; ISBN 8574785253.

48. Folke, C.; Haider, L.J.; Lade, S.J.; Norström, A.V.; Rocha, J. Commentary: Resilience and Social-Ecological Systems: A Handful of Frontiers. Glob. Environ. Chang. 2021, 71, 102400. [CrossRef]

49. Wolfram, M.; Borgström, S.; Farrelly, M. Urban transformative capacity: From concept to practice. Ambio 2019, 48, 437-448. [CrossRef] [PubMed]

50. Luederitz, C.; Brink, E.; Gralla, F.; Hermelingmeier, V.; Meyer, M.; Niven, L.; Panzer, L.; Partelow, S.; Rau, A.-L.; Sasaki, R.; et al. A review of urban ecosystem services: Six key challenges for future research. Ecosyst. Serv. 2015, 14, 98-112. [CrossRef]

51. Hobbs, R.J.; Higgs, E.S.; Hall, C. Novel Ecosystems: Intervening in the New Ecological World Order; John Wiley \& Sons: Hoboken, NJ, USA, 2013; ISBN 1118354206. 